\title{
PepN-like aminopeptidase from Lactobacillus curvatus DPC2024: purification and characterization
}

\author{
Abdallah A.A. Magboul, Paul L.H. McSweeney* \\ Department of Food Science and Technology, University College Cork, Ireland
}

(Received 2 November 1998; accepted 19 March 1999)

\begin{abstract}
An enzyme with a PepN-like aminopeptidase activity was purified 127 -fold with $4.3 \%$ recovery from a cell-free extract of Lactobacillus curvatus DPC2024, a component of the non-starter lactic acid bacterial flora of Cheddar cheese. The purified enzyme exhibited maximum activity on leucyl-p-nitroanilide (Leu-pNA) at $\mathrm{pH} 7.0$ and $40^{\circ} \mathrm{C}$. The enzyme had a molecular mass of $\sim 98 \mathrm{kDa}$ as estimated by gel permeation chromatography, and showed one band corresponding to a molecular mass of $\sim 95 \mathrm{kDa}$ on sodium dodecyl sulphate polyacrylamide gel electrophoresis (SDS-PAGE), indicating that the native enzyme existed as a monomer. The aminopeptidase appeared to be a metalloenzyme since it was strongly inhibited by ethylenediaminetetraacetic acid (EDTA) and $o$-phenanthroline at $0.1 \mathrm{mmol} \cdot \mathrm{L}^{-1}$ concentration and was partially reactivated by $\mathrm{Zn}^{2+}$ and $\mathrm{Co}^{2+}$. The enzyme was also partially inhibited by $p$-chloromercuribenzoate and iodoacetic acid, suggesting the involvement of sulphydryl groups in the reaction mechanism. The enzyme had a broad substrate specificity, hydrolysing a number of $p$-nitroanilide derivatives of amino acids and peptides and di-, tri-, tetra- and pentapeptides. The $\mathrm{N}$-terminal amino acid sequence of the first 20 amino acid residues was determined (AELMRFYQSFQPEHYQVFLD), and showed 40-55\% homology with $\mathrm{Zn}^{2+}$-dependent aminopeptidases from Streptococcus thermophilus NCDO53, Lactobacillus delbrueckii subsp. lactis DSM7290, Lactococcus lactis subsp. lactis MG1363 and Lactococcus lactis subsp. cremoris Wg2. (c) Inra/Elsevier, Paris.
\end{abstract}

aminopeptidase / PepN / Lactobacillus curvatus / purification

Résumé - Aminopeptidase de type PepN de Lactobacillus curvatus DPC2024 : purification et caractérisation. Une enzyme avec une activité aminopeptidasique de type PepN a été purifiée 127 fois avec un taux de récupération de $4,3 \%$ à partir d'un extrait sans cellule de Lactobacillus curvatus DPC 2024, un composant de la flore lactique non-levain du cheddar. L'enzyme purifiée possède une activité maximale sur le substrat leucyl-p-nitroanilide (Leu-pNA) à pH 7.0 et à $40^{\circ} \mathrm{C}$. La masse moléculaire de l'enzyme, déterminée par chromatographie d'exclusion par la taille, est de $\sim 98 \mathrm{kDa}$. Par SDS-PAGE, une bande correspondant à une masse moléculaire de $\sim 95 \mathrm{kDa}$ a été mise en évidence, indiquant que l'enzyme native existe sous forme de monomère. Cette aminopeptidase

*Correspondence and reprints. pmes@ucc.ie 
semble être une métalloenzyme car elle est fortement inhibée par l'EDTA et l'o-phenanthroline à la concentration de $0,1 \mathrm{mmol} \cdot \mathrm{L}^{-1}$ et est partiellement réactivée par $\mathrm{Zn}^{2+}$ et $\mathrm{Co}^{2+}$. L'enzyme est aussi partiellement inhibée par le $p$-chloromercuribenzoate et l'acide iodoacétique, suggérant l'implication de groupements sulfydryle dans le mécanisme de la réaction. L'enzyme a une large spécificité de substrat, hydrolysant un certain nombre d'acides aminés, de peptides, di-, tri-, tetra- et pentapeptides dérivés du $p$-nitroanilide. Les 20 premiers acides aminés de la séquence $\mathrm{N}$ terminale ont été identifiés (AELMRFYQSFQPEHYQVFLD). Une homologie de 40-55\% avec l'aminopeptidase $\mathrm{Zn}^{2+}$ dépendante des Streptococcus thermophilus NCDO53, Lactobacillus delbrueckii subsp. lactis DSM7290, Lactococcus lactis subsp. lactis MG1363 et Lactococcus lactis subsp. cremoris Wg2, a été observée. (c) Inra/Elsevier, Paris.

\section{aminopeptidase / PepN / Lactobacillus curvatus / purification}

\section{INTRODUCTION}

Lactobacilli, like most lactic acid bacteria $(\mathrm{LAB})$ used in dairy fermentations, are characterized by their multiple requirements for essential growth factors, including vitamins and amino acids [21]. As milk does not contain sufficient free amino acids and peptides to allow growth to high populations, lactobacilli possess a complex proteolytic system consisting of proteinases and peptidases, which enable these microorganisms to use the caseins in milk as an additional source of nitrogen $[24,31]$.

Several endo- and exopeptidases from lactobacilli have been isolated and studied biochemically and genetically $[15,17]$. Peptidases of lactobacilli are similar, but not identical, to corresponding enzymes from Lactococcus lactis which have been studied in more detail [15]. Amongst the most thoroughly studied of the exopeptidases from lactococci is a general aminopeptidase, PepN $[12,30,35]$. Aminopeptidases from other lactic acid bacteria with similar properties have also been characterized $[1,4-6$, $10,13,14,19,20,25,26,32,36]$. In most strains studied, the enzyme is a monomeric metallopeptidase of 87-97 kDa. Sequence alignments have shown that the gene encoding this enzyme ( $p e p N)$ is conserved amongst the dairy lactic acid bacteria $[6$, $14,30]$. PepN is a broad specificity aminopeptidase capable of hydrolyzing a wide range of peptide substrates differing in both size and amino acid composition $[1,20,23$, 26, 29, 30].

Mesophilic lactobacilli constitute most of the non-starter lactic acid bacteria (NSLAB) in Cheddar and Dutch-type cheeses $[11,37]$. These microorganisms typically gain entrance to the milk through postpasteurization contamination, but they also constitute part of the raw milk microflora and may survive pasteurization [34]. The typical strains of NSLAB found in Irish Cheddar cheese are facultatively heterofermentative lactobacilli and include $L b$. casei, Lb. plantarum, Lb. paracasei subsp. paracasei, Lb. curvatus and Lb. brevis [11]. The contribution of NSLAB to cheese flavour and flavour development is equivocal, but acceleration of cheese ripening occurs when certain strains are used as adjuncts [9].

A dimeric metal-independent aminopeptidase with high affinity for dipeptides has been purified and characterized from Lb. curvatus DPC2024 [18]. In this study, purification and characterization of a second aminopeptidase (PepN-like) from Lb. curvatus DPC2024 is described.

\section{MATERIALS AND METHODS}

\subsection{Chemicals}

Diethylaminoethyl (DEAE)-Sephacel, Phenyl Sepharose and Chelating Sepharose Fast Flow 
were purchased from Pharmacia, LKB Biotechnology Inc., Uppsala, Sweden. $p$-Nitroanilide derivatives of amino acids and peptides, di- tri-, oligopeptides and N-carbobenzyloxy (N-CBZ)blocked peptides were obtained from Bachem, Feinchemikalien, Bubendorf, Switzerland or Sigma Chemical Co., Saint-Louis, MO, USA. Deoxyribonuclease (DNase) I and ribonuclease (RNase) were obtained from Boehringer Mannheim GmbH, Mannheim, Germany. Molecular weight standards for gel permeation chromatography and sodium dodecyl sulphate polyacrylamide gel electrophoresis (SDS-PAGE) were purchased from the Sigma Chemical Co. All other chemicals and reagents used were of analytical grade.

\subsection{Microorganism and growth conditions}

Lb. curvatus DPC2024, which was originally isolated from a commercial pasteurized-milk Cheddar cheese [11], was obtained from the Dairy Products Research Centre, Moorepark, Fermoy, Co. Cork, Ireland. The organism was pre-cultured twice in de Man, Rogosa and Sharpe (MRS) broth (Oxoid, Unipath Ltd., Basingstoke, Hampshire, UK) at $30^{\circ} \mathrm{C}$. After $\sim 15 \mathrm{~h}$, pre-culture $(1 \% \mathrm{v} / \mathrm{v})$ was used to inoculate $20 \mathrm{~L}$ of the same medium. After incubation for $\sim 15 \mathrm{~h}$, cells were harvested by centrifugation $(5000 \mathrm{~g}$, $15 \mathrm{~min}, 4^{\circ} \mathrm{C}$ ) washed with $50 \mathrm{mmol} \cdot \mathrm{L}^{-1}$ tris(hydroxymethyl)aminomethane (Tris)- $\mathrm{HCl}$ buffer ( $\mathrm{pH} 7.0)$, and recentrifuged.

\subsection{Preparation of cell-free extract}

The cell-free extract was prepared from the washed cells by sonication as described by Magboul and McSweeney [18].

\subsection{Measurement of aminopeptidase activity}

Aminopeptidase activity was measured spectrophotometrically using leucyl-p-nitroanilide (Leu-pNA) as substrate as described by Magboul and McSweeney [18]. One unit (U) of aminopeptidase activity was defined as the amount of enzyme required to liberate $1 \mu \mathrm{mol} \cdot \mathrm{L}^{-1} p$-nitroaniline per min at $40{ }^{\circ} \mathrm{C}$ and $\mathrm{pH} 7.0$.

\subsection{Enzyme purification}

Protein contents of cell-free extract and pooled fractions were determined by the BioRad protein assay (BioRad Laboratories $\mathrm{GmbH}$, Munich, Germany) with bovine serum albumin as standard. The protein concentration in chromatographic effluents was measured by determining absorbance at $280 \mathrm{~nm}$.

Prior to chromatographic separation, the cellfree extract was concentrated by ultrafiltration (UF) using a Minitan UF unit fitted with polysulfone membranes with a $10 \mathrm{kDa}$ nominal molecular mass cutoff (Millipore Corp., Bedford, MA, USA). The concentrated cell-free extract was then dialyzed for $6 \mathrm{~h}$ at $4{ }^{\circ} \mathrm{C}$ against $50 \mathrm{mmol} \cdot \mathrm{L}^{-1}$ Tris-HCl buffer $(\mathrm{pH} 7.0)$.

The concentrated, dialyzed, cell-free extract was applied to a column $(70 \times 1.6 \mathrm{~cm})$ of DEAE-Sephacel, connected to a Gradifrac system (Pharmacia). The column was washed initially with $180 \mathrm{~mL}$ of $50 \mathrm{mmol} \cdot \mathrm{L}^{-1}$ Tris- $\mathrm{HCl}$ buffer ( $\mathrm{pH} 7.0$ ), followed by a linear $\mathrm{NaCl}$ gradient $\left(0-0.35 \mathrm{~mol} \cdot \mathrm{L}^{-1}\right)$ in the same buffer. The flow rate was $1.0 \mathrm{~mL} \cdot \mathrm{min}^{-1}$ and $15-\mathrm{mL}$ fractions were collected.

Active fractions from ion-exchange chromatography on DEAE-Sephacel were pooled and concentrated using a Centriprep- 3 concentrator (Amicon, Beverly, MA, USA). Ammonium sulphate was added to the concentrated sample to a final concentration of $1 \mathrm{~mol} \cdot \mathrm{L}^{-1}$ and then the sample was applied to a Phenyl Sepharose column $(20 \times 1.0 \mathrm{~cm})$ connected to a Gradifrac System (Pharmacia), which had previously been equilibrated with $20 \mathrm{mmol} \cdot \mathrm{L}^{-1}$ Tris- $\mathrm{HCl}(\mathrm{pH} 7.0)$ containing $1 \mathrm{~mol} \cdot \mathrm{L}^{-1}$ $\left(\mathrm{NH}_{4}\right)_{2} \mathrm{SO}_{4}$. The column was washed with the equilibration buffer $(50 \mathrm{~mL})$ and the proteins were eluted using a linear gradient from 1.0 to $0.0 \mathrm{~mol} \cdot \mathrm{L}^{-1}\left(\mathrm{NH}_{4}\right)_{2} \mathrm{SO}_{4}$ for $150 \mathrm{~mL}$, and then maintained at $0 \mathrm{~mol} \cdot \mathrm{L}^{-1}\left(\mathrm{NH}_{4}\right)_{2} \mathrm{SO}_{4}$ for $100 \mathrm{~mL}$. The flow rate was $0.5 \mathrm{~mL} \cdot \mathrm{min}^{-1}$ and $5-\mathrm{mL}$ fractions were collected.

Pooled active fractions from hydrophobic interaction chromatography were concentrated as described above and dialyzed for $4-6 \mathrm{~h}$ against $20 \mathrm{mmol} \cdot \mathrm{L}^{-1}$ Tris- $\mathrm{HCl}$ buffer ( $\mathrm{pH} 7.0$ ), containing $0.5 \mathrm{~mol} \cdot \mathrm{L}^{-1} \mathrm{NaCl}$. A chelating Sepharose column $(20 \times 1.6 \mathrm{~cm})$ immobilized with $\mathrm{Cu}^{2+}$ ( $15 \mathrm{~mL}$ of $4 \mathrm{mg} \cdot \mathrm{mL}^{-1} \mathrm{CuCl}_{2}$ ), connected to an FPLC system (Pharmacia), was equilibrated with $20 \mathrm{mmol}^{-\mathrm{L}^{-1}}$ Tris-HCl buffer ( $\mathrm{pH} 7.0$ ), containing $0.5 \mathrm{~mol} \cdot \mathrm{L}^{-1} \mathrm{NaCl}$. The dialyzed sample was applied to the column at a flow rate of $2 \mathrm{~mL}$ 
per min. The column was washed with twice its volume of equilibration buffer, and then proteins were eluted with a linear gradient from 0.0 to $0.12 \mathrm{~mol} \cdot \mathrm{L}^{-1}$ glycine in the same buffer. Fractions $(6 \mathrm{~mL})$ were then collected.

Active fractions from metal affinity chromatography were pooled and concentrated as described above. The concentrated sample was dialyzed against $20 \mathrm{mmol} \cdot \mathrm{L}^{-1}$ Tris $-\mathrm{HCl}$ buffer, $\mathrm{pH} 7.0$ for $\sim 3 \mathrm{~h}$ and then applied to a MonoQ HR5/5 column (Pharmacia) connected to an FPLC system. The column was washed with the starting buffer $\left(20 \mathrm{mmol} \cdot \mathrm{L}^{-1}\right.$ Tris- $\left.\mathrm{HCl}, \mathrm{pH} 7.0\right)$ for $7 \mathrm{~min}$, and then proteins were eluted from the column for $40 \mathrm{~min}$ by a linear gradient from 0.0 to $0.4 \mathrm{~mol} \cdot \mathrm{L}^{-1} \mathrm{NaCl}$ in the same buffer.

\subsection{Effect of $\mathrm{pH}$ and temperature on enzyme activity}

The effect of $\mathrm{pH}$ on the activity of the purified enzyme was determined in the range $4.0-9.5$ for $30 \mathrm{~min}$ at $40^{\circ} \mathrm{C}$, using $100 \mathrm{mmol} \cdot \mathrm{L}^{-1} \mathrm{Na}$-acetate, ( $\mathrm{pH} 4.0-6.0$ ) or $100 \mathrm{mmol} \cdot \mathrm{L}^{-1} 1,3$-bis[tris(hydroxymethyl)-methylamino]-propane (bisTris), (pH 6.5-9.5) buffers using Leu-pNA as substrate. The effect of temperature on Leu-pNA hydrolase activity was determined in the range $20-55^{\circ} \mathrm{C}$ in $50 \mathrm{mmol} \cdot \mathrm{L}^{-1}$ Tris $-\mathrm{HCl}$ buffer ( $\mathrm{pH}$ 7.0). For both $\mathrm{pH}$ and temperature optima, the activity was expressed as a percentage of the maximum activity.

\subsection{Heat stability}

The purified enzyme was incubated in $50 \mathrm{mmol} \cdot \mathrm{L}^{-1}$ Tris- $\mathrm{HCl}$ buffer $(\mathrm{pH} 7.0)$ at 40 , 45 or $50{ }^{\circ} \mathrm{C}$; aliquots $(50 \mathrm{~mL})$ of the enzyme solution at each temperature were withdrawn after $0,10,20,30,60$ and $100 \mathrm{~min}$. The residual activity was then determined on Leu-pNA at $\mathrm{pH}$ 7.0 and $40{ }^{\circ} \mathrm{C}$.

\subsection{Determination of purity and molecular mass}

The homogeneity of the active fractions after each purification step was examined by SDS-PAGE according to the method of Laemmli [16] with a $4 \%(w / v)$ acrylamide stacking and $12 \%(w / v)$ acrylamide separating gels. Proteins were stained using Coomassie brilliant blue
R-250 $(0.1 \% \mathrm{w} / \mathrm{v})$. The molecular mass of the enzyme was determined by sodium dodecyl sulphate polyacrylamide gel electrophoresis (SDS-PAGE) and by gel filtration chromatography on a TSK G2000 SW as described by Magboul and McSweeney [18].

\subsection{Effect of inhibitors, reducing agents and metal ions on enzyme activity}

The effect of metal ions, inhibitors and reducing agents was determined on the purified enzyme. The enzyme was dialyzed against water $\left(6 \mathrm{~h}, 4{ }^{\circ} \mathrm{C}\right)$ and pre-incubated in the presence of various compounds for $30 \mathrm{~min}$ at $40^{\circ} \mathrm{C}$ to a final concentration of $0.1,1.0$ or $10.0 \mathrm{mmol} \cdot \mathrm{L}^{-1}$ in $50 \mathrm{mmol} \cdot \mathrm{L}^{-1}$ Tris $-\mathrm{HCl}$ buffer, $\mathrm{pH} 7.0$. The enzyme activity was then determined on LeupNA $\left(40^{\circ} \mathrm{C}, 30 \mathrm{~min}\right)$.

\subsection{Substrate specificity}

The relative activity of the purified aminopeptidase against several pNA derivatives was determined as described above. Hydrolysis of peptide substrates was determined using a $\mathrm{Cd}$-ninhydrin assay as described by Magboul and McSweeney [18].

\subsection{N-terminal amino acid sequencing}

The first 20 amino acid residues of the purified aminopeptidase were determined as described by Magboul and McSweeney [18]. The EMBL database was searched for amino acid sequence alignments and homology using a PlastP search tool [40].

\section{RESULTS}

\subsection{Enzyme purification}

The purification of an aminopeptidase from the cell-free extract of $L b$. curvatus DPC2024 is summarized in table $I$ and chromatographic separations are shown in figure 1. Following anion-exchange chromatography on DEAE-Sephacel (figure 1A), 
Figure 1. Purification of an aminopeptidase from $L b$. curvatus DPC2024; protein concentration $\left(-, \mathrm{A}_{280}\right)$; salt gradient (- - ); aminopeptidase activity on Leu-pNA $\left(---\bullet---, \mathrm{A}_{410}\right)$. Elution profiles from (A) anion-exchange chromatography (DEAE-Sephacel); hydrophobic interaction chromatography (Phenyl Sepharose); (C) metalchelating affinity chromatography with immobilized $\mathrm{Cu}^{2+}$ (Chelating Sepharose Fast Flow); (D) FPLC anion-exchange chromatography (MonoQ HR 5/5).

Figure 1. Purification d'une aminopeptidase à partir de Lb. curvatus DPC2024 ; concentration en protéine $\left(-, \mathrm{A}_{280}\right)$; gradient de sel (- - ) ; activité aminopeptidasique sur Leu-pNA $\left(---\bullet--, \mathrm{A}_{410}\right)$. Profils d'élution (A) d'une chromatographie échangeuse d'ions ; (B) d'une chromatographie à interactions hydrophobes ; (C) d'une chromatographie d'affinité avec du $\mathrm{Cu}^{2+}$ immobilisé (Sepharose Fast Flow) ; (D) d'une chromatographie échangeuse d'anions FPLC (MonoQ HR 5/5).

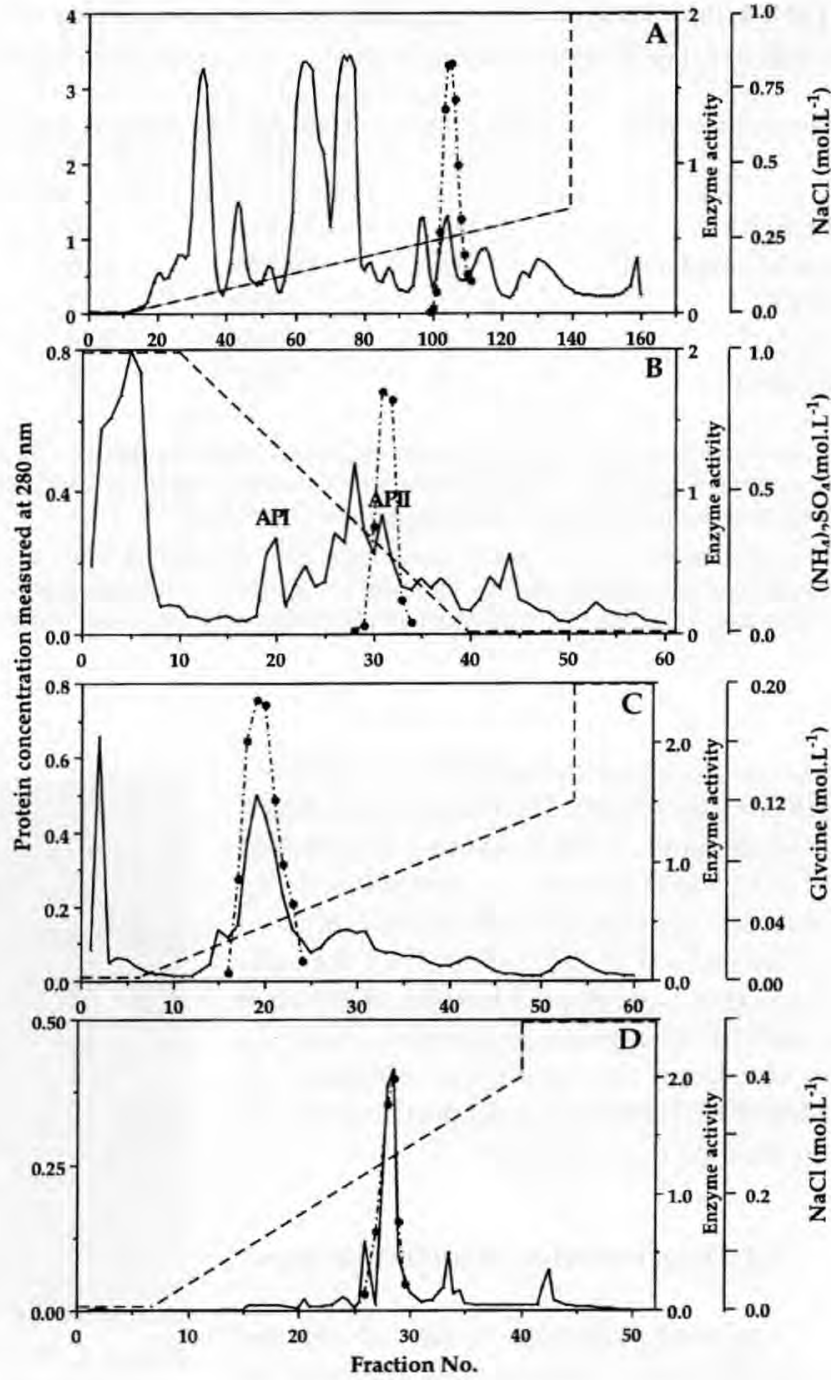

Leu-pNA hydrolase activity was eluted at $\sim 0.23 \mathrm{~mol} \cdot \mathrm{L}^{-1} \mathrm{NaCl}$ with a yield of $\sim 64 \%$ activity and 3-fold increase in specific activity. Chromatography on Phenyl Sepharose gave two Leu-pNA aminopeptidase activities (designated API and APII) eluted at $\sim 0.64$ and $0.3 \mathrm{~mol} \cdot \mathrm{L}^{-1}\left(\mathrm{NH}_{4}\right)_{2} \mathrm{SO}_{4}$, respectively (figure $1 B$ ). The purification and characterization of API is described elsewhere [18] and that of APII is described in this study. Hydrophobic interaction chromatog- raphy on Phenyl Sepharose increased APII activity 22 -fold over the concentrated cell-free extract with a yield of $19 \%$ (table I). Further purification of APII on chelating Sepharose resulted in a single peak with LeupNA activity which eluted at $\sim 0.04 \mathrm{~mol} \cdot \mathrm{L}^{-1}$ glycine (figure. $1 C$ ) with an activity yield of $17 \%$ and 107 -fold increase in specific activity over the concentrated cell-free extract (table I). Finally, the enzyme was purified by high-performance anion- 
Table I. Purification of an aminopeptidase from Lactobacillus curvatus DPC2024.

Tableau I. Purification d'une aminopeptidase à partir de Lactobacillus curvatus DPC2024 .

\begin{tabular}{lrcccc}
\hline Purification step & $\begin{array}{c}\text { Total protein } \\
(\mathrm{mg})\end{array}$ & $\begin{array}{c}\text { Total activity } \\
\text { (U) }\end{array}$ & $\begin{array}{c}\text { Specific activity } \\
\left(\mathrm{U} \cdot \mathrm{mg}^{-1}\right)\end{array}$ & $\begin{array}{c}\text { Purification } \\
\text { factor }\end{array}$ & $\begin{array}{c}\text { Activity yield } \\
(\%)\end{array}$ \\
\hline CCFE $^{\mathrm{a}}$ & 3744 & 22734 & 6 & 1 & 100 \\
DEAE-Sephacel $^{\mathrm{b}}$ & 877 & 14456 & 16.5 & 3 & 63.6 \\
HIC $^{\mathrm{c}}$ & 32 & 4329 & 135.2 & 22 & 19 \\
IMAC $^{\text {d }}$ & 6 & 3869 & 644.8 & 107 & 17 \\
MonoQ $^{\mathrm{e}}$ & 1.3 & 987 & 759 & 126.5 & 4.3 \\
\hline
\end{tabular}

${ }^{a}$ Concentrated cell-free extract; ${ }^{b}$ anion-exchange chromatography on DEAE-Sephacel; ${ }^{c}$ hydrophobic interaction chromatography on Phenyl Sepharose; ${ }^{\mathrm{d}}$ Chelating Sepharose Fast Flow immobilized with $\mathrm{Cu}^{2+} ;{ }^{\mathrm{e}}$ high performance anion-exchange chromatography on MonoQ HR5/5.

${ }^{a}$ Extrait concentré sans cellules ; ${ }^{b}$ chromatographie échangeuse d'anions sur DEAE-Sephacel ; ${ }^{c}$ chromatogra-

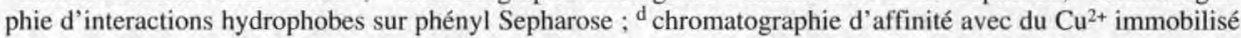
(Sepharose Fast Flow) ; ${ }^{\mathrm{e}}$ chromatographie échangeuse d'ions haute performance sur MonoQ HR 5/5.

exchange chromatography on MonoQ HR5/5 (figure 1D). The enzyme was eluted at $\sim 0.26 \mathrm{~mol} \cdot \mathrm{L}^{-1} \mathrm{NaCl}$, and this step resulted in a 127 -fold increase in specific activity over the concentrated cell-free extract with a yield of $4.3 \%$. SDS-PAGE of the cellfree extract and pooled fractions after each purification step was performed (figure 2). A single protein band was obtained on SDS-PAGE after the final purification step on MonoQ (lane 5, figure 2).

\subsection{Determination of molecular mass}

Apparent molecular masses of $\sim 95$ and $\sim 98 \mathrm{kDa}$ were estimated for the purified aminopeptidase by SDS-PAGE (figure 2) and high performance gel permeation chromatography (data not shown) respectively.

\section{3. $\mathrm{pH}$, temperature optima and heat stability}

The optimum $\mathrm{pH}$ for aminopeptidase activity was at $\mathrm{pH} 7.0$ and it retained less than $40 \%$ of its maximum activity at $\mathrm{pH}$ 5.5 and 8.0 (not shown). The optimum temperature for aminopeptidase activity was

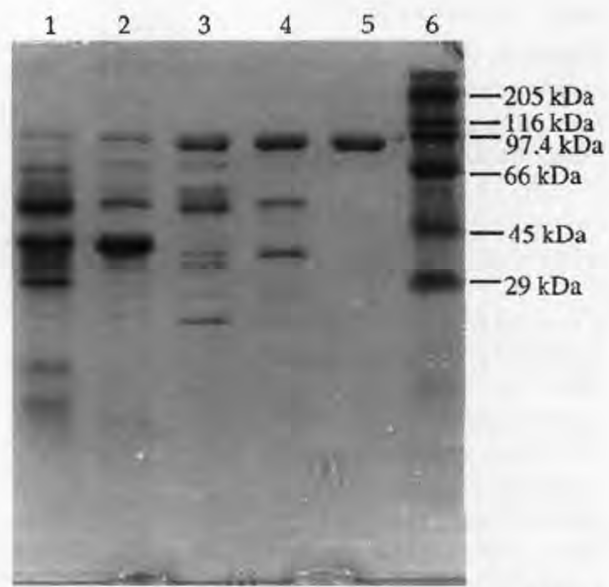

Figure 2. SDS-PAGE electrophotograms of fractions obtained during the purification of an aminopeptidase from $\mathrm{Lb}$. curvatus DPC2024. Lane 1: cell-free extract; lanes 2-5 are pooled active fractions after chromatography on DEAE-Sephacel, Phenyl Sepharose, Chelating Sepharose Fast Flow and MonoQ, respectively; lane 6: molecular weight standards.

Figure 2. Électrophorégrammes SDS-PAGE de fractions obtenues pendant la purification de 1'aminopeptidase de Lb. curvatus DPC2024. Bande 1 : extrait sans cellules ; bandes 2-5 : fractions actives regroupées après chromatographie sur DEAE-Sephacel, phényl Sepharose, Sepharose Fast Flow et MonoQ, respectivement ; bande 6 : standards de poids moléculaire. 
$40{ }^{\circ} \mathrm{C}$ at $\mathrm{pH} 7.0$ (not shown). The enzyme had more than $30 \%$ of its maximum activity at $20^{\circ} \mathrm{C}$ and less than $10 \%$ at $55^{\circ} \mathrm{C}$. The purified enzyme retained $\sim 78 \%$ of its maximum activity after heating at $45^{\circ} \mathrm{C}$ for $100 \mathrm{~min}$, but lost more than $95 \%$ of its activity after heating at $50{ }^{\circ} \mathrm{C}$ for $10 \mathrm{~min}$.

\subsection{Effect of inhibitors, reducing agents and metal ions}

The effects of inhibitors, reducing agents and metal ions are shown (table II). Metal chelating agents (ethylenediaminetetraacetic [EDTA] acid and $o$-phenanthroline) strongly inhibited enzyme activity. Complete inhibition and $70 \%$ reduction in enzyme activ- ity were observed after pre-incubation of enzyme solutions in $0.1 \mathrm{mmol} \cdot \mathrm{L}^{-1}$ EDTA and $o$-phenanthroline, respectively. Aminopeptidase activity, inhibited by EDTA and $o$-phenanthroline, was partially restored by 0.05 and $0.1 \mathrm{mmol} \cdot \mathrm{L}^{-1} \mathrm{Co}^{2+}$ and $\mathrm{Zn}^{2+}$ (data not shown). Thiol blocking agents (e.g., $p$-chloromercuribenzoate and iodoacetic acid) at a concentration of 1 and $10 \mathrm{mmol} \cdot \mathrm{L}^{-1}$ caused pronounced inhibition of aminopeptidase activity. Phenylmethylsulfonyl fluoride (PMSF) and $\mathrm{N}$-ethylmaleimide had no effect on the enzyme activity at concentrations of 0.1 or $1 \mathrm{mmol} \cdot \mathrm{L}^{-1}$, although the serine protease inhibitor, PMSF, caused $93 \%$ inhibition of the aminopeptidase activity at $10 \mathrm{mmol} \cdot \mathrm{L}^{-1}$. The reducing agents dithiothreitol and $\beta$-mercaptoethanol caused sig-

Table II. Effect of different compounds on the activity of an aminopeptidase purified from Lactobacillus curvatus DPC2024.

Tableau II. Effet de différents composés sur l'activité de l'aminopeptidase purifiée à partir de Lactobacillus curvatus DPC2024.

\begin{tabular}{lrrr}
\hline Compounds & \multicolumn{3}{c}{$\begin{array}{c}\text { Residual activity (\%) } \\
\text { Concentration }\left(\mathrm{mmol} \cdot \mathrm{L}^{-1}\right)\end{array}$} \\
\cline { 2 - 4 } & 0.1 & 1 & 10 \\
\hline None & 100 & 100 & 100 \\
Ethylenediaminetetraacetic acid & 0 & 0 & 0 \\
o-Phenanthroline & 32 & 0 & 0 \\
p-Chloromercuribenzoate & 82 & 39 & 2 \\
N-Ethylmaleimide & 95 & 79 & 78 \\
Phenylmethylsulfonyl fluoride & 110 & 104 & 7 \\
Iodoacetic acid & 74 & 58 & 0 \\
$\beta-\mathrm{Mercaptoethanol}^{-}$ & 98 & 60 & 38 \\
$\mathrm{Dithiothreitol}_{\mathrm{CaCl}}$ & 69 & 55 & 26 \\
$\mathrm{CoCl}_{2}$ & 92 & 83 & 80 \\
$\mathrm{CdCl}_{2}$ & 338 & 410 & 057 \\
$\mathrm{CuCl}_{2}$ & 40 & 9 & 0 \\
$\mathrm{FeCl}_{3}$ & 39 & 6 & 0 \\
$\mathrm{HgCl}_{2}$ & 29 & 0 & 0 \\
$\mathrm{MgCl}_{2}$ & 0 & 0 & 186 \\
$\mathrm{MnCl}_{2}$ & 126 & 31 & 22 \\
$\mathrm{NiCl}_{2}$ & 62 & 54 & 0 \\
$\mathrm{ZnCl}_{2}$ & 98 & 94 & 19 \\
\hline & 139 & & \\
\hline
\end{tabular}


Table III. Substrate specificity of the aminopeptidase purified from $L b$. curvatus DPC2024.

Tableau III. Spécificité de substrat de l'aminopeptidase purifiée à partir de Lb. curvatus DPC2024.

\begin{tabular}{|c|c|c|c|c|c|c|c|}
\hline \multirow{2}{*}{$\begin{array}{l}\text { Substrate } \\
\text { Leu-pNA* }\end{array}$} & $\begin{array}{l}\text { Relative activity } \\
(\%)^{\mathrm{a}}\end{array}$ & \multirow{2}{*}{$\begin{array}{l}\text { Substrate } \\
\text { Ala-Pro }\end{array}$} & \multirow{2}{*}{$\begin{array}{r}\text { Relative activity } \\
(\%)^{\mathrm{b}}\end{array}$} & \multirow{2}{*}{$\begin{array}{l}\text { Substrate } \\
\text { Ala-Ala }\end{array}$} & $\begin{array}{r}\text { Relative activity } \\
(\%)^{\mathrm{b}}\end{array}$ & \multicolumn{2}{|c|}{$\begin{array}{r}\text { Substrate Relative activity } \\
(\%)^{\mathrm{b}}\end{array}$} \\
\hline & 100 & & & & 10 & Val-Pro-Leu & 0 \\
\hline Ala-pNA & 6 & Asp-Leu & 0 & Ala-Leu & 14 & Pro-Phe-Gly-Lys & 0 \\
\hline Gly-pNA & 0 & Glu-Val & 0 & Ala-Lys & 20 & Ala-Ala-Ala-Ala & 24 \\
\hline Glu-pNA & 0 & His-Leu & 27 & Ala-Met & 17 & $(\mathrm{Ala})_{5}$ & 79 \\
\hline Lys-pNA & 63 & His-Val & 0 & Ala-Phe & 10 & & \\
\hline Pro-pNA & 0 & Leu-Ala & 17 & Pro-Pro & 0 & & \\
\hline Val-pNA & 0 & Leu-Arg & 52 & Tyr-Phe & 48 & & \\
\hline Phe-pNA & 58 & Leu-Gly & 17 & N-CBZ-Phe-Gly & 0 & & \\
\hline Met-pNA & 26 & Leu-Leu* & 100 & N-CBZ-Ala-Phe & 0 & & \\
\hline His-pNA & 0 & Leu-Pro & 0 & Ala-Ala-Ala & 265 & & \\
\hline Arg-Pro-pNA & 0 & Leu-Trp & 55 & Ala-Leu-Gly & 62 & & \\
\hline Ala-Ala-Pro-pNA & 0 & Leu-Val & 31 & Arg-Pro-Pro & 0 & & \\
\hline & & Lys-Leu & 24 & Gly-Pro-Arg & 0 & & \\
\hline & & Met-Ala & 17 & Leu-Ala-Pro & 345 & & \\
\hline & & Phe-Ala & 65 & Leu-Gly-Gly & 145 & & \\
\hline & & Phe-Gly & 20 & Leu-Leu-Leu & 76 & & \\
\hline & & Pro-Ala & 0 & Met-Leu-Gly & 231 & & \\
\hline & & Pro-Gly & 0 & Phe-Gly-Pro & 262 & & \\
\hline & & Pro-Leu & 0 & Met-Leu-Pro & 345 & & \\
\hline & & Pro-Phe & 0 & Pro-Gly-Gly & 0 & & \\
\hline
\end{tabular}

* Activity was expressed relative to the rates of hydrolysis of Leu-pNA $\left({ }^{a}\right)$ or Leu-Leu $\left({ }^{b}\right)$ which were taken as $100 \%$.

* L'activité est exprimée en fonction des taux d'hydrolyse du Leu-pNA ( $\left.{ }^{(}\right)$ou Leu-Leu (b) qui peuvent atteindre $100 \%$. 
nificant inhibition of the enzyme activity at 1 and $10 \mathrm{mmol} \cdot \mathrm{L}^{-1}$.

The aminopeptidase purified from Lb. curvatus DPC2024 was slightly activated by $0.1 \mathrm{mmol} \cdot \mathrm{L}^{-1} \mathrm{Zn}^{2+}$ and by 0.1 , 1 and $10 \mathrm{mmol} \cdot \mathrm{L}^{-1} \mathrm{Mg}^{2+}$. Very strong activation was observed following treatment with $0.1,1$ and $10 \mathrm{mmol} \cdot \mathrm{L}^{-1} \mathrm{Co}^{2+}$. Complete inhibition of enzyme activity was caused by $\mathrm{Hg}^{2+}$ at $0.1 \mathrm{mmol} \cdot \mathrm{L}^{-1}, \mathrm{Fe}^{3+}$ at $1 \mathrm{mmol} \cdot \mathrm{L}^{-1}$ and by $\mathrm{Cu}^{2+}, \mathrm{Cd}^{2+}$ and $\mathrm{Ni}^{2+}$ at $10 \mathrm{mmol} \cdot \mathrm{L}^{-1}$. Strong inhibition of aminopeptidase activity was observed for $\mathrm{Fe}^{3+}$, $\mathrm{Cu}^{2+}, \mathrm{Cd}^{2+}$ and $\mathrm{Ni}^{2+}$ at 0.1 or $1 \mathrm{mmol} \cdot \mathrm{L}^{-1}$ and by $\mathrm{Zn}^{2+}$ at $10 \mathrm{mmol} \cdot \mathrm{L}^{-1}$.

\subsection{Substrate specificity}

The relative rates of hydrolysis of several substrates by the aminopeptidase purified from $L b$. curvatus DPC2024 were determined (table $I I I)$. The highest rates of hydrolysis for $p$-nitroanilide derivatives were observed with Leu-pNA, followed by LyspNA, Phe-pNA and Met-pNA. A lower hydrolysis rate was observed for Ala-pNA, while no hydrolysis was observed using Gly-pNA, Glu-pNA, Asp-pNA, Pro-pNA, Val-pNA, His-pNA, Arg-Pro-pNA or AlaAla-Pro-pNA as substrate.

The enzyme showed broad specificity and hydrolyzed a range of di-, tri-, tetra- and pentapeptides. The enzyme hydrolyzed some of the tripeptides (e.g., Leu-Ala-Pro, Met-Leu-Pro, Ala-Ala-Ala, Phe-Gly-Pro, Met-Leu-Gly and Leu-Gly-Gly) at a faster rate than Leu-Leu (table III). N-Terminalblocked dipeptides and dipeptides with Asp and Glu at the N-terminus or di- and tripeptides with Pro at the first or second position were not hydrolyzed by this enzyme.

\section{6. $\mathrm{N}$-Terminal amino acid sequencing}

The amino acid sequence of the first 20 residues of aminopeptidase purified from Lb. curvatus DPC2024 and the corresponding amino acid sequence of aminopeptidases from Streptococcus thermophilus NCDO53 [19], Lb. delbrueckii subsp. lactis DSM7290 [14], Lactococcus lactis subsp. lactis [33], Lc. lactis subsp. lactis MG1363 [30, 35] and Lc. lactis subsp. cremoris $\mathrm{Wg} 2$ [27] are shown in table IV.

\section{DISCUSSION AND CONCLUSION}

Lactobacillus curvatus DPC2024 is one of the mesophilic Lactobacillus strains which were originally isolated from a commercial pasteurized-milk Irish Cheddar cheese [11]. Facultatively heterofermentative

Table IV. Amino acid sequence alignments of the $\mathrm{N}$-terminal residues of the aminopeptidase purified from $L$ b. curvatus DPC2024 (A) and PepN-type aminopeptidases from Sc. thermophilus NCDO53 (B), Lb. delbrueckii subsp. lactis DSM 7290 (C), Lc. lactis subsp. lactis (D) and Lc. lactis subsp. lactis MG1363 and Lc. lactis subsp. cremoris Wg2 (E).

Tableau IV. Séquence d'acides aminés des résidus N-terminaux de l'aminopeptidase purifiée à partir de $L$ b. curvatus DPC2024 (A) et de l'aminopeptidase de type PepN à partir de Sc. thermophilus NCD053 (B), Lb. delbrueckii subsp. lactis DSM7290 (C), Lc. lactis subsp. lactis (D) et Lc. lactis subsp. lactis MG1363 et Lc. lactis subsp. cremoris Wg2 (E).

\begin{tabular}{|c|c|c|c|c|c|c|c|c|c|c|c|c|c|c|c|c|c|c|c|c|c|}
\hline (A) & & $A_{1}$ & $E$ & $\mathrm{~L}$ & M & $\mathrm{R}$ & $\mathrm{F}$ & $\mathrm{Y}$ & $Q$ & $S$ & $\mathrm{~F}$ & Q & $P$ & E & $\mathrm{H}$ & $\mathrm{Y}$ & Q & V & F & L & $\mathrm{D}_{20}$ \\
\hline (B) & $\mathrm{T}_{1}$ & $\mathrm{~A}_{2}$ & S & V & A & $\mathrm{R}$ & F & I & $\mathrm{E}$ & $\mathrm{S}$ & $\mathrm{F}$ & I & $P$ & E & $\mathrm{N}$ & Y & X & L & F & $\mathrm{L}_{20}$ & \\
\hline (C) & & $\mathrm{M}_{\mathrm{I}}$ & A & V & $\mathrm{K}$ & $\mathrm{R}$ & F & Y & E & $\mathrm{T}$ & $\mathrm{F}$ & $\mathrm{H}$ & P & D & $\mathrm{H}$ & $\mathrm{Y}$ & D & L & $\mathrm{Y}$ & I & $\mathrm{D}_{20}$ \\
\hline (D) $\mathrm{M}_{1}$ & $\mathrm{~T}_{2}$ & $\mathrm{~A}_{3}$ & S & V & A & $\mathrm{R}$ & F & I & $\mathrm{E}$ & $\mathrm{S}$ & $\mathrm{F}$ & I & P & E & $\mathrm{N}$ & Y & $\mathrm{N}$ & L & $F$ & L & $\mathrm{D}_{22}$ \\
\hline (E) & & $M_{1}$ & $\mathrm{~A}_{2}$ & V & K & $\mathrm{R}$ & $\mathrm{L}$ & I & E & $\mathrm{T}$ & $\mathrm{F}$ & V & P & E & $\mathrm{N}$ & Y & K & I & $\mathrm{F}$ & L & $\mathrm{D}_{20}$ \\
\hline
\end{tabular}


lactobacilli dominate the NSLAB flora of Cheddar and Dutch-type cheeses [11, 37] and it is believed that they make a positive contribution to cheese flavour when used as adjuncts [9]. Two aminopeptidases active on Leu-pNA (API and APII) have been purified and characterized from the cell-free extract of $L b$. curvatus DPC2024. Purification and characterization of API has been described by Magboul and McSweeney [18], and APII is described in this study.

APII was purified to homogeneity in four chromatographic steps with $\sim 127$-fold increase in specific activity over the concentrated cell-free extract. The native enzyme existed as a monomer of $\sim 95 \mathrm{kDa}$, as suggested by SDS-PAGE and gel permeation chromatography. This compares well with the molecular masses of PepN-type aminopeptidases characterized from $L$. lactis subsp. cremoris (strains Wg2, MG1363 and HP), Lb. delbrueckii subsp. lactis DSM7290, Lb. delbrueckii subsp. bulgaricus B14 and $L b$. helveticus (strains LHE511, CNRZ32, ITGL1 and SBT2171) [8, 15].

The aminopeptidase described in this study had maximum activity on Leu-pNA at $\mathrm{pH} 7.0$ and $40^{\circ} \mathrm{C}$. Heating at $\mathrm{pH} 7.0$ and $45^{\circ} \mathrm{C}$ for up to $100 \mathrm{~min}$ caused $\sim 23 \%$ decrease in enzyme activity, but the enzyme lost more than $80 \%$ of its activity after preincubation at $50^{\circ} \mathrm{C}$ for $10 \mathrm{~min}$. Most of the PepN and PepN-like aminopeptidases characterized from Lactococcus, Streptococcus and Lactobacillus have maximum activity at $\mathrm{pH}$ values around neutrality and at temperatures between $35-50{ }^{\circ} \mathrm{C}[8,15]$. The aminopeptidase from $\mathrm{Lb}$. delbrueckii subsp. bulgaricus $\mathrm{B} 14$ showed maximum activity at $\mathrm{pH} 7.0$ and $50{ }^{\circ} \mathrm{C}$, and retained $90 \%$ of its activity after heating at $48^{\circ} \mathrm{C}$ for $5.5 \mathrm{~h}$.

The aminopeptidase from $L b$. curvatus DPC2024 characterized in this study appeared to be a metallopeptidase, since it was strongly inhibited by $0.1 \mathrm{mmol} \cdot \mathrm{L}^{-1}$ EDTA and $o$-phenanthroline and was activated by $\mathrm{Co}^{2+}, \mathrm{Mg}^{2+}$ and $\mathrm{Zn}^{2+}$. The apoenzyme formed by the treatment with
$0.1 \mathrm{mmol} \cdot \mathrm{L}^{-1}$ EDTA and $o$-phenanthroline was partially reactivated by 0.05 and $0.1 \mathrm{mmol} \cdot \mathrm{L}^{-1} \mathrm{Co}^{2+}$ and $\mathrm{Zn}^{2+}$. All of the PepN-type aminopeptidases characterized to date from LAB are metalloenzymes, strongly inhibited by EDTA and $o$-phenanthroline and, in some cases, this inhibition may be fully or partially restored by different divalent metal ions $[5,38]$. The enzyme was also partially inhibited by thiol reducing or blocking agents, indicating that thiol groups are important for aminopeptidase activity. Inhibition by thiol reagents was observed for a number of PepN and PepNlike aminopeptidases $[1,2,5,7,13,20,26$, 28].

Like most general aminopeptidases, the enzyme purified in this study showed broad specificity and hydrolyzed $p$-nitroanilide derivatives of amino acids (e.g. Leu-pNA, Lys-pNA), di-, tri-, tetra- and pentapeptides. The enzyme did not hydrolyze di- and tripeptides with proline residues at the first or second position, in agreement with the substrate specificity of many general aminopeptidases $[1,5,19,22,25,28]$ with the exceptions of metallopeptidases from Lb. delbrueckii subsp. bulgaricus B14 [39] and $L b$. helveticus SBT 2171 [26].

The sequence of the first 20 amino acid residues of the purified aminopeptidase showed 40-55\% homology with N-terminal amino sequences of PepN-type aminopeptidases from S, thermophilus NCDO53 [19], Lb. delbrueckii subsp. lactis DSM7290 [14], Lc. lactis [33], Lc. lactis subsp. lactis MG1363 [30, 35] and Lc. lactis subsp. cremoris Wg2 [27].

These results indicated that the aminopeptidase characterized in this study is closely related to PepN-type aminopeptidases isolated from strains of Lactobacillus, Streptococcus and Lactococcus.

The aminopeptidase characterized in this study was dissimilar to the other aminopeptidase [API; 18] characterized from the same strain with respect to hydrophobicity, metal dependency, molecular mass, substrate 
specificity and $\mathrm{N}$-terminal amino acid sequence. The presence of more than one leucyl-aminopeptidase activity was suggested for $L b$. delbrueckii subsp. bulgaricus CNRZ 397 and Lb. helveticus ITGL2/3 by Atlan et al. [3] and Blanc et al. [4], respectively.

The function of peptidases in LAB is partly to provide the organism with a suitable source of amino acids, but the action of peptidases during cheese ripening is also important in contributing directly to cheese flavour by releasing single amino acid residues or indirectly when these free amino acids act as flavour precursors or when peptidases hydrolyze bitter peptides to shorter non-bitter peptides. Due to the presumed involvement of mesophilic lactobacilli in the development of cheese flavour during ripening, and since the NSLAB grow to high cell densities $\left(>10^{7} \mathrm{cfu} \cdot \mathrm{g}^{-1}\right.$ cheese [8]) during ripening, purification and characterization of individual peptidases from these strains may help to elucidate the role of their peptidolytic system in the development of cheese flavour.

\section{ACKNOWLEDGEMENTS}

This research has been part-funded by grant aid under the Food Sub-Programme of the Operational Programme for Industrial Development which is administered by the Department of Agriculture, Food and Forestry, and supported by national and EU Funds. Our thanks and gratitude to A. Healy for the amino acid sequencing.

\section{REFERENCES}

[1] Arora G., Lee B.H., Purification and characterization of aminopeptidase from Lactobacillus casei subsp. casei LLG, J. Dairy Sci. 75 (1992) 700-710.

[2] Arora G., Lee B.H., Purification and characterization of an aminopeptidase from Lactobacillus casei subsp. rhamnosus S93, Biotechnol. Appl. Biochem. 19 (1994) 179-192.

[3] Atlan D., Laloi P., Portalier R., Isolation and characterization of aminopeptidase-deficient Lactobacillus bulgaricus mutants, Appl. Environ. Microbiol. 55 (1989) 1717-1723.
[4] Blanc B., Laloi P., Atlan D., Gilbert C., Portalier R., Two cell-wall-associated aminopeptidases from Lactobacillus helveticus and the purification and characterization of APII from strain ITGL1, J. Gen. Microbiol. 139 (1993) 1441-1448.

[5] Bockelmann W., Schulz Y., Teuber M., Purification and characterization of an aminopeptidase from Lactobacillus delbruekii subsp. bulgaricus, Int. Dairy J. 2 (1992) 95-107.

[6] Christensen J.E., Lin D., Palva A., Steele J.L., Sequence analysis, distribution and expression of an aminopeptidase $\mathrm{N}$-encoding gene from Lactobacillus helveticus CNRZ 32, Gene 155 (1995) 89-93.

[7] Exterkate F.A., De Jong M., De Veer G.J.C.M., Baankreis R., Location and characterization of aminopeptidase $\mathrm{N}$ in Lactococcus lactis subsp. cremoris HP, Appl. Microbiol. Biotechnol. 37 (1992) 46-54.

[8] Fox P.F., McSweeney P.L.H., Proteolysis in cheese during ripening, Food Rev. Int. 12 (1996) 457-509.

[9] Fox P.F., Wallace J.M., Lynch C.M., Niland E.J. Tobin J., Acceleration of cheese ripening, Antonie van Leeuwenhoek 70 (1996) 271-297.

[10] Gobbetti M., Smacchi E., Corsetti A., The proteolytic system of Lactobacillus sanfrancisco CB 1: purification and characterization of a proteinase, a dipeptidase and an aminopeptidase, Appl. Environ. Microbiol. 62 (1996) 3220-3226.

[11] Jordan K.N., Cogan T.M., Identification and growth of non-starter lactic acid bacteria in Irish Cheddar cheese, Irish J. Agric. Food Res, 32 (1993) 47-55.

[12] Kaminogawa S., Ninomiya T., Yamauchi K., Aminopeptidase profiles of lactic streptococci, J. Dairy Sci. 67 (1984) 2483-2492.

[13] Khalid N.M., Marth E.H., Partial purification and characterization of an aminopeptidase from Lactobacillus helveticus CNRZ32, Syst. Appl. Microbiol. 13 (1990) 311-319.

[14] Klein J.R., Klein U., Schad M., Plapp R., Cloning, DNA sequence analysis and partial characterization of pepN, a lysyl aminopeptidase from Lactobacillus delbrueckii subsp. lactis DSM7290, Eur. J. Biochem. 217 (1993) 105-114.

[15] Kunji E.R.S., Mierau I., Hagting A., Poolman B., Konings W.N., The proteolytic system of lactic acid bacteria, Antonie van Leeuwenhoek 70 (1996) 187-221.

[16] Laemmli U.K., Cleavage of structural proteins during the assembly of the head of bacteriophage $\mathrm{T}_{4}$, Nature (Lond.) 227 (1970) 196-204.

[17] Law J, Haandrikman A., Proteolytic enzymes of lactic acid bacteria, Int. Dairy J. 7 (1997) 1-11.

[18] Magboul A.A.A., McSweeney P.L.H., Purification and characterization of an aminopeptidase from Lactobacillus curvatus DPC2024, Int. Dairy J. (1999) in press. 
[19] Midwinter R.G., Pritchard G.G., Aminopeptidase N from Streptococcus salivarius subsp. thermophilus NCDO 573: purification and properties, J. Appl. Bacteriol. 77 (1994) 288-295.

[20] Miyakawa H., Kobayashi S., Shimamura S., Tomita M., Purification and characterization of an aminopeptidase from Lactobacillus helveticus LHE-511, J. Dairy Sci. 75 (1992) 27-35.

[21] Morishita T., Deguchi Y., Yajima M., Sakurai T., Yura, T., Multiple nutritional requirements of lactobacilli: genetic lesions affecting amino acid biosynthetic pathways, J. Bacteriol. 148 (1981) 64-71.

[22] Neviani E., Boquien C.Y., Monnet V., Phan Thanh L., Gripon J.C., Purification and characterization of an aminopeptidase from Lactococcus lactis subsp. cremoris AM2, Appl. Environ. Microbiol. 55 (1989) 2308-2314.

[23] Niven G.W., Holder S.A., Stroman P., A study of the substrate specificity of aminopeptidase $\mathrm{N}$ from Lactococcus lactis subsp, cremoris, Appl. Microbiol. Biotechnol. 44 (1995) 100-105.

[24] Pritchard G.G., Coolbear T., The physiology and biochemistry of the proteolytic system in lactic acid bacteria, FEMS Microbiol. Rev. 12 (1993) 179-206.

[25] Rul F., Monnet V., Gripon J.C., Purification and characterization of a general aminopeptidase (st-PepN) from Streptococcus salivarius subsp. thermophilus CNRZ 302, J. Dairy Sci. 77 (1994) 2880-2889.

[26] Sasaki M., Bosman B.W., Tan P.S.T., A new, broad-substrate-specificity aminopeptidase from the dairy organism Lactobacillus helveticus SBT 2171, Microbiology 142 (1996) 799-808.

[27] Stroman P., Sequence of a gene (lap) encoding a 95.3-kDa aminopeptidase from Lactococcus lactis subsp. cremoris Wg2, Gene 113 (1992) 107-112.

[28] Tan P.S.T, Konings W.N., Purification and characterization of an aminopeptidase from Lactococcus lactis subsp. cremoris Wg2, Appl. Environ. Microbiol. 56 (1990) 526-532.

[29] Tan P.S.T., Chapot-Chartier M.P., Pos K.M., Rousseau M., Boquien C.Y., Gripon J,C., Konings W.N., Localization of peptidases in lactococci, Appl. Environ. Microbiol, 58 (1992) 285-290.

[30] Tan P.S.T., van Alen-Boerrigter I.J,, Poolman B., Siezen R.J., de Vos W.M., Konings W.N., Char- acterization of the Lactococcus lactis pepN gene encoding an aminopeptidase homologous to mammalian aminopeptidase N, FEBS Lett. 306 (1992) 9-16.

[31] Thomas T.D., Pritchard G.G., Proteolytic enzymes of dairy starter cultures, FEMS Microbiol. Rev. 46 (1987) 245-268.

[32] Tsakalidou E., Kalantzopoulos G., Purification and partial characterization of an intracellular aminopeptidase from Streptococcus salivarius subsp, thermophilus strain ACA-DC 114, J. Appl. Bacteriol. 72 (1992) 227-232.

[33] Tsukasak F., Motoshima H., Minagawa E., Kaminogawa S, Aminopeptidase N (lysyl aminopeptidase) sequence from Lactococcus lactis subsp. lactis, Direct submission to EMBL/GENBANK/ database, 1996, Accession No. 2499896

[34] Turner K.W., Lawrence R.C., Lelieux J., A microbiological specification for milk for aseptic cheese making, N.Z. J. Dairy Sci. Technol. 21 (1986) 249-254.

[35] van Alen-Boemigter LJ, Baankreis R., de Vos W.M., Characterization and overexpression of the $\mathrm{Lac}$ tococcus lactis pepN gene and localization of its products, aminopeptidase N, Appl. Environ. Microbiol. 57 (1991) 2555-2561.

[36] Varmanen P., Vesanto E., Steele J.L., Palva A., Characterization and expression of the pepN gene encoding a general aminopeptidase from Lactobacillus helveticus, FEMS Microbiol. Lett. 124 (1994) 315-320.

[37] Williams G., Banks J.M., Proteolytic and other hydrolytic enzyme activities in non-starter lactic acid bacteria (NSLAB) isolated from Cheddar cheese manufactured in the United Kingdom, Int. Dairy J. 7 (1997) 763-774.

[38] Wohlrab Y., Bockelman W., Purification and characterization of a second aminopeptidase (PepC-like) from Lactobacillus delbrueckii subsp. bulgaricus B14, Int. Dairy J. 3 (1993) 685-701.

[39] Wohlrab Y., Bockelmann W., Purification and characterization of a new aminopeptidase from Lactobacillus delbrueckii subsp. bulgaricus B14, Int. Dairy J. 4 (1994) 409-427.

[40] Worley K.C., Wiese B.A., Smith R.F., Beauty: enhanced BLAST-based search tool that integrates multiple biological information resources into sequence similarity search results, Gene Res. 5 (1995) 173-184. 